\title{
ARTIFnS
}

Universidade de Franca,

CAMILA DE ARAÚJO BERALDO LUDOVICE

São Paulo, Brasil

LAYD GLAUCE FONTANEZI NOGUEIRA

Universidade de Franca, São Paulo, Brasil

\section{"IMAGINA A FESTA": COMERCIAL DA BRAHMA E A PARÓDIA CRIADORA DE NOVO SENTIDO}

\section{RESUMO}

Este trabalho tem como objetivo analisar os discursos e as relações dialógicas da paródia e do anúncio publicitário da Brahma, que fez referência à Copa do Mundo de 2014 no Brasil. A dinâmica que organiza a sociedade só pode ser compreendida com um olhar atento em direção às articulações entre publicidade, mídia e consumo, uma vez que está constantemente impregnado o conteúdo da vida urbana. Assim, inspirada no comercial de TV, a paródia, que teve grande sucesso entre os internautas que acessam as redes e mídias sociais, consegue apresentar um novo ponto de vista sobre o mesmo tema. Dessa maneira, procura-se discutir a importância desses dois recursos para a constituição dos sentidos, já que o dialogismo permite a inserção de outras ideologias existentes e

palavras-chave dialogismo; paródia; publicidade; redes e mídias sociais. com a paródia é possível inferir que se ganha um sentido diferente do original, mas o conteúdo parodiado sempre é valorizado e perpetuado. 


\section{CONSIDERAÇÕES INICIAIS}

Este artigo objetiva analisar e discutir sobre os discursos, as relações dialógicas e a paródia a partir do anúncio publicitário da Brahma, denominado "imagina a festa", que fez referência à Copa do Mundo de 2014 no Brasil. A escolha em retratar o diálogo entre o comercial de TV da Brahma ${ }^{1}$ e o vídeo com sua paródia deveu-se ao fato de que a dinâmica que organiza a sociedade só pode ser compreendida com um olhar atento em direção às articulações entre publicidade, mídia e consumo, uma vez que está constantemente impregnado o conteúdo da vida urbana. Isso se relaciona ao fato de que a paródia trouxe imagens em contraponto ao texto dito pela campanha, que continua o mesmo na paródia, mudando-se apenas as imagens e, mesmo assim, conseguiu ser associativo, crítico e principalmente dialogar e fazer alusão, por ser repleta de crítica social, que leva o receptor a pensar e a questionar se o país estaria realmente preparado, se aquele seria o melhor momento para receber a Copa do Mundo, se aquele evento traria mesmo algum benefício relativamente importante ao país, considerando o expressivo investimento público. Além disso, a escolha foi também motivada pelo grande sucesso que a paródia do anúncio fez entre os internautas, ${ }^{2}$ que acessam as redes e mídias sociais como meio de comunicação.

Na perspectiva de Bakhtin, o discurso pode ser produzido a partir de diferentes pontos de vista, por isso, priorizam-se tanto as vozes sociais e os estilos individuais. No ato de se comunicar, relações dialógicas são estabelecidas para expressar uma opinião e reproduzir enunciados anteriores, visto que os discursos são sociais e, embora não sejam completamente novos, jamais se repetem. Portanto, de acordo com Bakhtin (2000), todo enunciado é individual e, por isso, pode refletir a individualidade de quem fala. A voz individual só se faz ouvir ao se integrar com outras vozes já presentes, estabelecendo, assim, o dialogismo.

Dessa maneira, Bakhtin postula que todo enunciado será notado quando permitir ao outro a possibilidade de réplica. Assim, os enunciados, os textos e os discursos devem ser analisados como participantes de uma história, de uma cultura e de um acontecimento.

\footnotetext{
1. Brahma é uma marca de cerveja brasileira criada em 1888, no Rio de Janeiro, pela Manufactura de Cerveja Brahma Villiger \& Companhia, que depois mudaria de nome para Companhia Cervejaria Brahma, e depois seria sucedida pela AmBev. Cervejas Brahma. Disponível em: <http://www.ambev.com.br/marcas/cervejas/brahma/brahma-chopp/>. Acesso em: 19 out. 2016.

2. Internauta: usuário interativo da rede internacional Internet. Dicionário Brasileiro da Língua Portuguesa - Michaelis / online UOL. Disponível em: <http://michaelis.uol.com.br/ busca?id=V4wnz>. Acesso em: 19 out. 2016.
} 
Para a realização deste artigo, utilizou-se uma metodologia que se inicia primeiramente com a escolha da paródia do anúncio da Brahma "Imagina a Festa". O vídeo, que foi muito visualizado nas redes sociais e comentado na mídia em geral, retrata, de forma irônica, uma visão recente do Brasil e conduz à reflexão do que seria ter uma visão pessimista ou otimista demais sobre o evento esportivo que aconteceu em terras brasileiras em 2014.

Como metodologia, utilizou-se a pesquisa bibliográfica a partir de uma revisão sobre as reflexões do círculo de Mikhail Bakhtin sobre dialogismo e paródia, assim como os estudos de Linda Hutcheon também sobre paródia.

A escolha dos conceitos de dialogismo e paródia como base da análise deveu-se, sobretudo, ao caráter crítico e irônico presentes. A esse respeito, será abordada a forma como estes dois recursos foram explorados no vídeo parodiado, de modo a garantir o tom reflexivo e de crítica social que tanto agradou os internautas. É importante salientar que a paródia criada será o recurso mais amplamente analisado, já que se sabe que o sentido gerado será constituído, na maioria das vezes, por ela.

Ao longo da análise, procura-se discutir também a importância desses dois recursos para a constituição dos sentidos, já que, com a paródia, é possível inferir que se ganha um sentido diferente do original, pelo fato de que a paródia distorce o sentido original e cria um novo sentido, sendo uma via de mão dupla, na medida em que marca a diferença em vez de semelhança, e o dialogismo permite a inserção de outras ideologias existentes.

Como dito anteriormente, a análise realiza-se em torno do discurso do comercial da Brahma "Imagina a festa" e sua paródia criada em forma de vídeo. A partir dos conceitos de discurso publicitário, dialogismo e paródia, procura-se verificar a importância que tais recursos têm na criação de novos discursos. Como forma de iniciar a teoria, será exposta uma breve apresentação dos conceitos de Bakhtin sobre dialogismo. Em seguida, serão apresentados estudos teóricos sobre a publicidade como meio de comunicação, sobre o discurso publicitário em estudiosos dessa teoria, como Jean Baudrillard e Fred Tavares, e sobre os conceitos de paródia, já que a análise será voltada para a definição que os autores aqui estudados deram a estes conceitos. 0 estudo sobre a paródia será baseado em Mikhail Bakhtin e o círculo e nos estudos de Linda Hutcheon.

\section{DIALOGISMO}

Todo produto ideológico parte de uma realidade (natural ou social), possui um significado e remete a algo que lhe é exterior, ou seja, é um signo. os signos são, também, passíveis de avaliações ideológicas, já que não 
existem apenas como item passivo da realidade: eles refletem e refratam outras realidades (Bakhtin-Volochinov 1988, 31).

Um signo é compreendido a partir de outro. A consciência individual tem como base a ideologia impregnada. No entanto, ela só se revela no processo de interação social:

Os signos são o alimento da consciência individual, a matéria de seu desenvolvimento, e ela reflete sua lógica e suas leis. A lógica da consciência é a lógica da comunicação ideológica, da interação semiótica de um grupo social. Se privarmos a consciência de seu conteúdo semiótico e ideológico, não sobra nada (Bakhtin-Volochinov 1988, 35- 36).

Bakhtin valoriza a fala, a enunciação e esta, por sua vez, não tem natureza individual, estando, assim, ligada às condições histórico-ideológicas de classes na sociedade. "A palavra é o fenômeno ideológico por excelência. Ela é o modo mais puro e sensível de relação social" (Bakhtin-Volochinov 1988, 36). A palavra é um signo neutro, já que cabe em diversas esferas e acompanha toda criação ideológica.

Para Bakhtin (2000), é por meio do dialogismo que se constrói o sentido de um discurso e se estabelece a linguagem. De acordo com Bakhtin, citado por Fiorin (2006), o dialogismo estabelece a interação verbal entre as diferentes classes sociais por meio da linguagem, da palavra carregada de sentidos e de marcas ideológicas. Assim, é possível acontecer a comunicação.

[...] todo enunciado é dialógico. Portanto, o dialogismo é o modo de funcionamento real da linguagem, é o princípio constitutivo do enunciado. Todo enunciado constitui-se a partir de outro enunciado, é uma réplica a outro enunciado (Fiorin 2006, 24).

Segundo Brait (1997, p. 98), o "dialogismo diz respeito às relações que se estabelecem entre o eu e o outro nos processos discursivos instaurados historicamente pelos sujeitos que, por sua vez, instauram-se e são instaurados por esses discursos".

Bakhtin (1997) apresenta dois modos de pensar o dialogismo: o diálogo entre os interlocutores e o diálogo entre discursos. Diante da condição do outro no registro da subjetividade: a reação da palavra à palavra já dita, o enlace dos dizeres anteriores. A relação dialógica pressupõe um estado de ebulição criadora que precisa ser despertado. Segundo Velmezova (2005, 76), "as fronteiras existem para serem ultrapassadas". Essa troca acontece porque as retomadas do discurso do outro sofrem desarranjos e produzem outros sentidos imprevisíveis. 
Sobre o conceito de dialogismo, Bakhtin afirma que este retoma algo já posto e produz sentidos que se materializam no discurso. Por meio de alianças e rupturas, as vozes alternam sentidos antigos e novos, sempre marcados por efeitos de anterioridade e transformação. Sendo assim, não há limites para um discurso dialógico, pois sempre gera perguntas e automaticamente respostas, já que brechas ficam abertas para originar outros discursos.

A enunciação significativa propõe uma réplica, conforme Marchezan (2006, 117), seja esta de concordância, apreciação ou discrepância. A enunciação pode ser compreendida quando colocada em confronto com os próprios dizeres e com os dizeres de outrem. Dessa maneira, os enunciados são compreendidos quando despertam no indivíduo ideologias.

Dialogar com a cultura alheia significa abrir perguntas ao outro e, ao mesmo tempo, buscar, no outro, respostas para as suas interpelações, descobrindo, assim, novas possibilidades de sentido (Zavala, 2009, 153). Um texto está sempre em diálogo com outros textos. Assim, na visão bakhtiniana, o diálogo é social, pois sempre pode ser reformulado. Ainda segundo Bakhtin, todo gênero é dialógico.

\section{A PUBLICIDADE COMO MEIO DE COMUNICAÇÃO}

A publicidade é um forte meio de comunicação com a sociedade, uma vez que ela emite uma mensagem e que existe um receptor que a recebe e a assimila. A publicidade tem que cumprir com as responsabilidades sociais e com a sua principal proposta, que é comunicar.

A comunicação como influenciadora de ideologias está constantemente incentivando posicionamentos, o que implica que as empresas ficam cada vez mais convencidas de que estão impondo ações positivas. "A publicidade tem por tarefa divulgar as características deste ou daquele produto e promover-lhe a venda. Esta função 'objetiva' permanece em princípio sua função primordial.” (Baudrillard 1997, 174).

De acordo com Baudrillard (1997), a publicidade, apesar de persuasiva e de estar submetida às leis de venda e de lucro, é democrática, já que é oferecida a todos. Somente a mercadoria é vendida; a publicidade é ofertada.

Para Tavares (2005), a publicidade é uma mensagem paga que, por meio de apelos racionais e emocionais, faz uso de recursos linguísticos e estilísticos de ordenação, persuasão e sedução. A publicidade divulga produtos, bens e serviços e estabelece a popularidade e credibilidade de uma marca perante o público consumidor. No entanto, ela sozinha não consegue criar demanda e satisfazer plenamente o cliente se o produto, 
bem ou serviço não tiver qualidade e não corresponder às expectativas do consumidor. A função informativa da publicidade tem o objetivo de estabelecer uma relação de comunicação entre potenciais consumidores e produtos, bens e serviços capazes de satisfazer as necessidades sociais.

A principal função da publicidade é atrair consumidores, de forma a tornar as mercadorias ou serviços mais desejáveis. A principal tarefa da publicidade é acrescentar no público o desejo pelas mercadorias. Segundo Tavares (2005, p. 126), "a publicidade produz utiliza valores, saberes e naturaliza os desejos do consumo, tornando-os necessidades básicas, simbolizando-os por meio da ideologia de aceitação e pertencimento, compartilhada por todos como um ideal de existência".

O valor simbólico é produzido no imaginário das pessoas. A mercadoria só concorre para realizar seu valor de troca conforme se converte em imagem, converte-se também em signo. Baudrillard (1997) diz que, para se tornar objeto de consumo, é preciso que o objeto se torne signo. Assim sendo, o consumidor não bebe cerveja, bebe Brahma.

Hoje, os valores, em bilhões de dólares, que as marcas assumem são graças a seus produtos, bens e serviços, mas, principalmente, à publicidade. Muitas empresas podem perder todo o seu patrimônio e ainda assim ficariam com um patrimônio milionário graças as suas valiosas marcas. Das oito marcas mais caras do mundo (Coca-Cola, ${ }^{3}$ Microsoft, ${ }^{4} \mathrm{IBM},{ }^{5} \mathrm{GE},{ }^{6}$

\footnotetext{
3 Coca-Cola é o refrigerante mais vendido em todo o mundo. É produzido pela The Coca-Cola Company, sediada em Atlanta, Estados Unidos. A história da Coca-cola. Disponível em: <http://www.cocacolabrasil.com.br/sobre-a-coca-cola-brasil/a-historia-da-coca-cola-brasil>. Acesso em: 19 out. 2016.

4 Microsoft: é uma empresa transnacional americana com sede em Redmond, Washington, que desenvolve, fabrica, licencia, apoia e vende softwares de computador, produtos eletrônicos, computadores e serviços pessoais. Microsoft - Institucional. Disponível em: <https:// www.microsoft.com/pt-br/about/nossa-companhia.aspx>. Acesso em: 19 out. 2016.

5 IBM: International Business Machines (IBM) é uma empresa dos Estados Unidos voltada para a área de informática. Sobre a IBM. Disponível em: https://www.ibm.com/ibm/br/ pt/?lnk=fsi-saib-brpt. Acesso em: 19 out. 2016.

6 GE: General Electric Company, também conhecida por GE, é uma empresa multinacional americana de serviços e de tecnologia. Sobre a GE. Disponível em: <https://www.ge.com/ br/sobre>. Acesso em: 19 out. 2016.
} 
Intel Inside, ${ }^{7}$ Walt Disney, ${ }^{8}$ McDonald's ${ }^{9}$ e Nokia, ${ }^{10}$ nesta ordem), em quatro delas, a marca vale mais do que as próprias empresas.

Sem dúvida, a publicidade tem o poder de acrescentar valor aos produtos, bens, serviços e às marcas. Sem a publicidade, nada disso seria o que realmente é ou teria o valor que tem. É a arte da publicidade que faz com que o consumidor enxergue magia e encantamento. (Bucci 2002, 57).

Atualmente, o público tem diversos produtos, bens e serviços disponíveis; nessa hora, a falta de conhecimento das qualidades, informação ou complexidade tecnológica dificultam ainda mais a escolha. Logo, a escolha do público consumidor pelo melhor produto, bem ou serviço se dá pela comunicação publicitária, por intermédio de seu discurso.

A utilização do discurso publicitário como ferramenta de comunicação sustenta uma argumentação que leva o receptor a ser atingido pela atenção do emissor em relação ao objeto. Assim, a publicidade impõe, nas linhas e entrelinhas, valores, mitos, ideais e outras elaborações simbólicas, utilizando os recursos próprios da língua, que lhe serve de veículo (Tavares 2005).

Dessa maneira, o discurso publicitário, por meio de uma comunicação mais sugestiva, apresenta uma soma de valores agregados ao produto, bem ou serviço que o torna superior às outras marcas, captando a atenção do consumidor ao mesmo tempo em que o orienta a fazer a escolha ideal. Esta é uma característica marcante no discurso publicitário.

7 Intel Inside: é uma empresa multinacional, que fabrica circuitos integrados como microprocessadores e outros chipsets. Visão geral sobre a empresa Intel Inside. Disponível em: <www.intel.com.br/content/www/br/pt/company-overview/company-overview.html>. Acesso em: 19 out. 2016.

8 Walt Disney: The Walt Disney Company, conhecida simplesmente como Disney, é uma companhia multinacional estadunidense de mídia de massa sediada no Walt Disney Studios, em Burbank, Califórnia. É um dos maiores conglomerados de mídia e entretenimento do planeta. Walt Disney Company - About. Disponível em: <https://thewaltdisneycompany.com/about/>. Acesso em: 19 out. 2016.

9 McDonald's é a maior cadeia mundial de restaurantes de fast food de hambúrguer, servindo em 119 países através de 35 mil pontos de venda. Fundada em1955, Illinois EUA. Mc Donald's Quem somos. Disponível em: <http://www.mcdonalds.com.br/>. Acesso em: 19 out. 2016.

10 Nokia: Nokia Corporation, conhecida como Nokia, é uma empresa multinacional finlandesa detelecomunicações e tecnologia, fundada em 1865. Nokia Company - About us. Disponível em: <http://company.nokia.com/en/about-us/our-company>. Acesso em: 19 out. 2016. 


\section{O DISCURSO PUBLICITÁRIO NO COMERCIAL DA BRAHMA "IMAGINA A FESTA"}

A campanha otimista criada pela agência África para a Brahma foi baseada na expressão "imagina na copa", tão repercutida no Brasil. 0 anúncio denominado "imagina a festa" fez referência à Copa do Mundo de 2014, realizada no Brasil.

Em geral, o uso da expressão "imagina na copa" era associado a problemas de segurança e infraestrutura que o país enfrentava e ainda enfrenta. Muitos brasileiros encararam o evento com pessimismo e desconfiança desde a divulgação do Brasil como país sede da Copa do Mundo de 2014. Muitos se questionaram se aquele seria o melhor momento e se o Brasil estaria mesmo pronto para receber a Copa do Mundo de futebol em 2014. "Um discurso é sempre uma mensagem situada, produzida por alguém e endereçada a alguém." (Verón 1980, 77).

Durante todo o anúncio "Imagina a Festa", divulgado em setembro de 2012, o discurso elaborado como um recado aos pessimistas lista os motivos que fariam o país sediar a denominada "melhor copa do mundo já feita", frase dita até mesmo pela presidente Dilma Rousseff, à época. "Todo o discurso publicitário sobre as necessidades dos indivíduos assenta numa antropologia ingênua: a da propensão natural para felicidade" (Baudrillard 1995, 47. o discurso publicitário influencia o indivíduo. Ele carrega elementos psicológicos, sociológicos, antropológicos e utiliza linguagem própria. Tudo isso para satisfazer os anunciantes e levar o consumidor a desejar tão fortemente determinado produto, bem ou serviço a ponto de fazer com que esse público consumidor trabalhe para satisfazer seu desejo a qualquer custo, transformando assim esse desejo em necessidade verdadeira (Bigal 1999).

o discurso publicitário é um dos instrumentos de controle social e, para bem realizar essa função, simula o igualitarismo, remove da estrutura da superfície os indicadores de autoridade e poder, substituindo-os pela linguagem da sedução com o objetivo de produzir o consumo." (Carvalho 1996, 11)

O discurso publicitário do comercial da Brahma - "Imagina a Festa" utiliza uma comunicação incentivadora, e não de manipulação direta. Ele é composto por recursos estilísticos e argumentativos, voltados a transmitir melhor as ideias. De acordo com Tavares (2005), a própria fala é um recurso comunicativo que ilustra bem o modelo publicitário de discurso, já que, por meio da fala, ocorre a argumentação de ideias impostas para convencer o público.

A diferença está no grau de consciência quanto aos recursos utilizados e, nesse sentido, a publicidade se caracteriza pela 
utilização racional de tais instrumentos para convencer, modificar e manter a opinião e a percepção do público-alvo quanto a uma determinada ideia, produto ou marca. (Tavares 2005, 11)

A persuasão do discurso publicitário presente neste comercial da Brahma consiste no apelo à emoção do consumidor. Com intuito de provar o que se afirma ao tentar inverter a expectativa sobre o evento, o comercial da Brahma não faz um discurso meramente ufanista, mas sim com muita adequação ao posicionamento de uma marca de cerveja. Tudo é uma questão de estratégia de manipulação para conquistar o público. Esse modelo secular proposto por Aristóteles ${ }^{11}$ está fundado sob as retóricas emocional, racional e institucional. Para Aristóteles, o estilo deliberativo está impregnado em todo discurso que tem o objetivo de convencer, persuadir e modificar alguma opinião ou ideia a fim de obter uma reação do receptor (Tavares 2005).

No que corresponde ao discurso publicitário do comercial da Brahma, com todos os efeitos de produção bem elaborados, modernos e atrativos, o foco é, sem dúvida, a interação com seu público, ou seja, todo discurso produzido foi feito para prender a atenção. O público, como sujeito pensante, ativo, crítico e detentor de opiniões, ideologias e memória, consequentemente, participa da provocação dos sentidos.

A imagem tem papel importante na construção da argumentação persuasiva do anúncio publicitário. Ao lado das palavras, ela forma um todo repleto de significação por meio da apresentação visual e textual do produto.

A imagem publicitária é sobrecarregada de todo o tipo de códigos culturais. Dessa maneira, o anúncio publicitário sempre terá um significado comum que atende ao público, de forma a não perder a sua essência. 0 texto publicitário, por natureza, é um texto deliberativo.

O discurso publicitário no comercial da Brahma - "imagina a festa" é estruturado no modelo indicativo lúdico, já que o discurso é implicitamente representado na forma de ideal, sonho, desejo de poder. Assim, apresenta-se uma capacidade de manipulação e influência justamente por inserir a mensagem otimista da marca, utilizando-se de artifícios culturais impregnados no cotidiano dos brasileiros.

\footnotetext{
11 Aristóteles: filósofo grego, aluno de Platão e professor de Alexandre, o Grande. Seus escritos abrangem diversos assuntos, como a física, a metafísica, as leis da poesia e do drama, a música, a lógica, a retórica, o governo, a ética, a biologia e a zoologia. Juntamente com Platão e Sócrates, Aristóteles é visto como um dos fundadores da filosofia ocidental. Aristóteles Biografia. Disponível em: <http://www.pucsp.br/pos/cesima/schenberg/alunos/paulosergio/biografia.html>. Acesso em: 19 out. 2016.
} 
Os anúncios publicitários enfatizam, magicamente, o sentido de um poder que se legitima pela ordem de um espetáculo, no qual o receptor tem um papel e um script a seguir, que é o de ser consumidor (identidade) e um contexto de consumo como enunciado de pertencimento, idolatria, controle e aceitação social. (Tavares 2005, 21)

Dessa maneira, o anúncio da Brahma "Imagina a Festa" se apoderou do bordão "imagina na copa", que tanto foi dito pelos brasileiros ao depararem com situações sociais problemáticas que ocorriam e ainda ocorrem no Brasil. Com isso, o discurso do comercial da Brahma ostentou a todo o momento o potencial que o Brasil possuía de fazer algo que entraria para a história, ou seja, a melhor copa do mundo já feita e a maior festa do planeta já vista. Com isso, toda visão considerada pessimista é menosprezada, tornando-se pequena demais se comparada ao que todo o evento poderia proporcionar ao Brasil e aos brasileiros.

\subsection{AS IMAGENS PUBLICITÁRIAS DO COMERCIAL DA BRAHMA - "IMAGINA A FESTA"}

As imagens reforçam a escrita por serem de fácil e rápida leitura, de forma a complementar ao mesmo tempo em que dá suporte à escrita. A imagem tem papel importante na construção da argumentação persuasiva do anúncio publicitário. Ao lado das palavras, ela forma um todo repleto de significação por meio da apresentação visual e textual do produto. Dondis (2003) afirma que a atividade de olhar ou ver é um processo que requer pouca energia e que há uma forte tendência à informação visual no comportamento humano. Sendo assim, os publicitários fazem bastante uso de elementos visuais para fazer com que os anúncios sejam mais atrativos e persuasivos.

De acordo com Martins, (1997, 12), "O uso correto das palavras, o argumento usado para convencer o leitor, a relação coerente entre imagem/ linguagem, a objetividade e a originalidade do conteúdo são cuidados especiais para apresentar o produto de maneira atraente."

Nesse anúncio publicitário, as imagens exercem a função de reforçar aquilo que a linguagem verbal se afirma, em uma relação de complementaridade entre imagem e texto, uma vez que os elementos visuais são os principais responsáveis por aproximar o público da marca, fazendo com que ocorra uma identificação imediata com esta e com o desejo de consumir, já que a atividade publicitária do comercial tem como propósito persuadir o receptor e criar algo que seja rapidamente identificado pelo público. Assim, o anúncio publicitário, ao se materializar em textos verbais e visuais, gera discurso por meio de estratégias criativas. 
As imagens produzidas pela agência de publicidade nesse comercial da marca de cervejas Brahma foram analisadas, a fim de verificar de que modo ocorreu a apropriação de elementos otimistas do imaginário social brasileiro, com o objetivo de incentivar a visão otimista sobre o evento, já que os brasileiros são considerados demasiadamente otimistas. Em meio a um contexto social de desigualdade, sofrimento e carência política, econômica e sociocultural, ainda conseguem ter bom ânimo para tudo, ainda mais se tratando de futebol, festas e carnaval, que são consideradas as principais paixões do povo da nação brasileira.

Baudrillard (1995) diz que a publicidade tem como tarefa não somente informar ao consumidor as características dos produtos para promover sua venda, uma vez que essa função objetiva da publicidade está muito além de sua função primordial. Dessa forma, as imagens publicitárias, como um segundo produto de consumo, além dos objetos que ela divulga, a sua própria existência faz com que todos consumam, ao mesmo tempo, uma categoria e sua imagem.

Barthes (1987) diz, sobre o caráter das imagens publicitárias, que estas colocam à disposição alguns equivalentes funcionais do mito. 0 autor utiliza o termo mito para designar significações desprovidas de seus sentidos históricos e políticos que dão lugar a sentidos ideológicos, assim como ocorre na publicidade. Para o autor, os mitos e as imagens publicitárias frequentemente solucionam contradições sociais, fornecem modelos de identidade e engrandecem a ordem social vigente.

A propaganda da Brahma começa com a imagem de um corredor cheio de troféus de campeonatos de futebol, ganhos pelo Brasil. No teto desse lugar, é possível ver uma iluminação que forma a imagem de um campo de futebol. À medida que vai ficando mais iluminado e próximo, é possível ver ao centro desse lugar uma sambista vestida para o carnaval, sambando e transmitindo alegria como se estivesse na avenida em um desfile com a escola de samba e seus tambores batendo ao ritmo do carnaval (Figura 1).

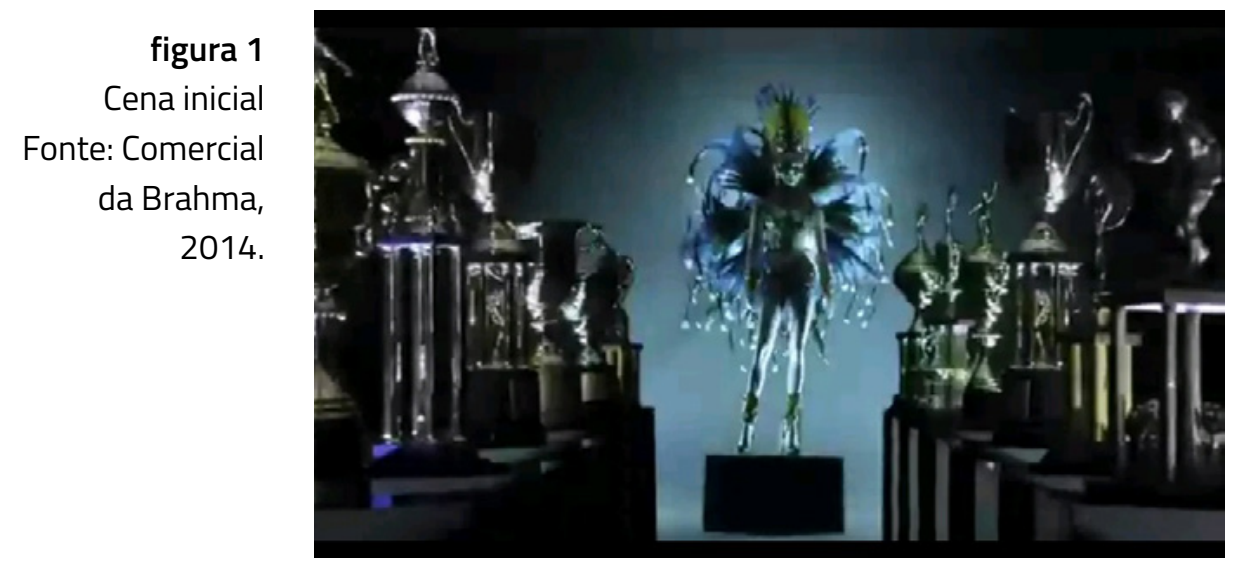


A matéria prima da publicidade e da mídia provém dos elementos do imaginário: representações, concepções de mundo, valores, interpretações da realidade, ou seja, de um universo simbólico. Isso significa que as mensagens publicitárias se constituem em torno da associação de elementos simbólicos aos produtos e às marcas. Desse modo é que a eficácia da publicidade se efetiva.

A dimensão da mensagem publicitária como bem e imagem consumível é fruto da sua relação com a mídia, o que quer dizer que ambas se complementam ao constituírem uma estratégia de autopromoção econômica e simbólica, em que a mídia e publicidade se nutrem reciprocamente.

Na próxima imagem do comercial, o futebol é retratado com festa, emoção e muita paixão, como se o Brasil tivesse conquistado um título mundial. Até essa parte do anúncio publicitário, foram destacadas as duas maiores paixões dos brasileiros: o futebol e o carnaval (Figuras 2 e 3).

\section{figura 2 \\ Futebol. \\ Fonte: Comercial \\ da Brahma, 2014.}

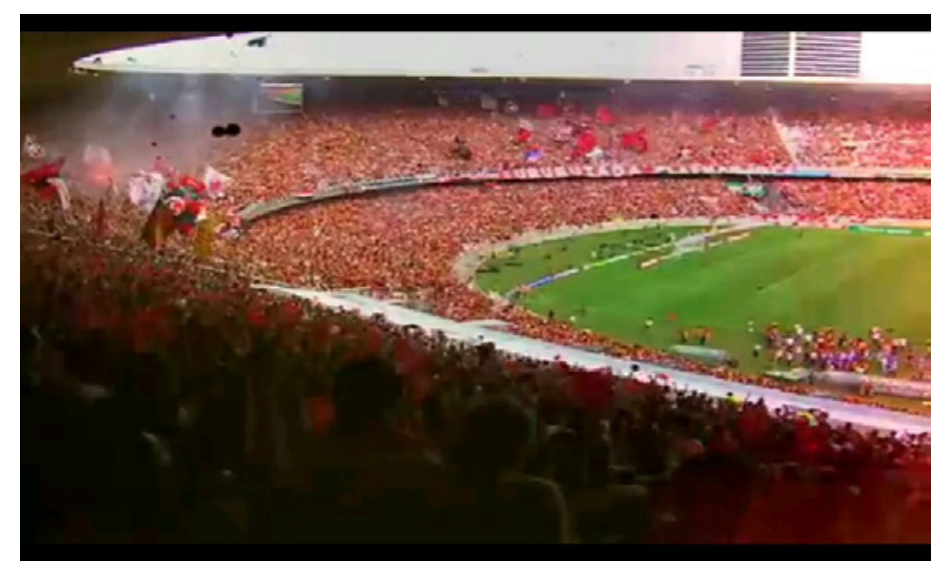

figura 3

Carnaval.

Fonte: Comercial da Brahma, 2014.

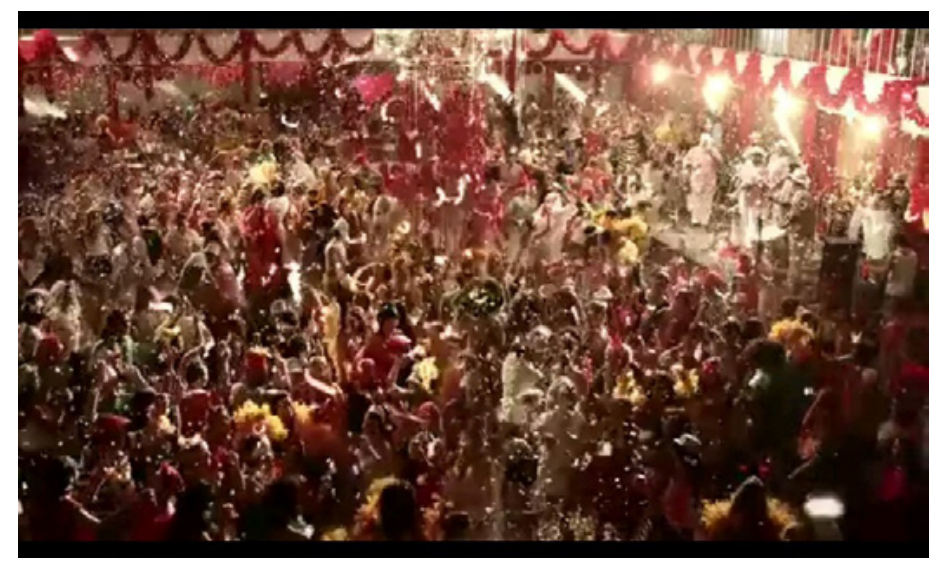


De acordo com Fiorin (2006), a teoria bakhtiniana prioriza as vozes sociais e também as vozes individuais, e o discurso pode ser produzido a partir de pontos de vista. Na parte seguinte, o comercial transmite crítica à visão pessimista do evento que muitos vinham tendo da realização de uma Copa do Mundo no Brasil em 2014.

Baudrillard explica sobre a construção de sentido nas imagens da publicidade:

Tanto quanto a tranquilidade que ela oferece de uma imagem jamais negativa, somos sensíveis à manifestação fantástica de uma sociedade capaz de ultrapassar a estrita necessidade dos produtos na superfluidade das imagens, somos sensíveis à sua virtude de espetáculo, de jogo, de encenação. (Baudrillard 1997, 181)

A postura adotada pela Brahma conferiu à marca uma posição que difere totalmente daquela adotada por parte da população e considerada até então pessimista. Essa campanha publicitária tentou incorporar certas imagens que buscam associar seu produto a características socialmente desejáveis, sendo ainda mais promovido à medida que o anúncio utiliza a imagem de uma personalidade admirada do futebol brasileiro, com sucesso, aprovação social e fama, que é o ex-jogador de futebol, apelidado como Ronaldo Fenômeno, ${ }^{12}$ por ser um atleta de alto nível e conhecido mundialmente na história do futebol.

Dessa maneira, Rojek $(2008,201)$ aponta o poder que a imagem de uma celebridade exerce na perspectiva de convencer parte da sociedade:

A cultura da celebridade é, portanto, em parte a expressão de um eixo cultural organizado em torno do desejo abstrato. É uma ferramenta essencial de transformação em mercadoria, visto que personifica o desejo. Em particular, ela proporciona aos consumidores padrões atraentes de emulação. Por outro lado, a distância entre celebridade e fã e a constante inovação na cultura da celebridade redobram a qualidade abstrata no desejo de massa.

O fato de celebridades aparecerem nos comerciais remete à sensação de aproximação com o ídolo, pois, na maioria das vezes, são personalidades admiradas pelo público.

12 Ronaldo Luís Nazário de Lima, mais conhecido como Ronaldo Fenômeno, é um ex-futebolista brasileiro que atuava como atacante e é considerado um dos melhores e mais conhecidos jogadores da história do futebol brasileiro e mundial. Ronaldo Fenômeno História de vida. Disponível em: <http://esporte.ig.com.br/futebol/ronaldo/11237863664000. html>. Acesso em: 19 out. 2016. 
figura 4

Pessimistas.

Fonte: Comercial

da Brahma,

2014.

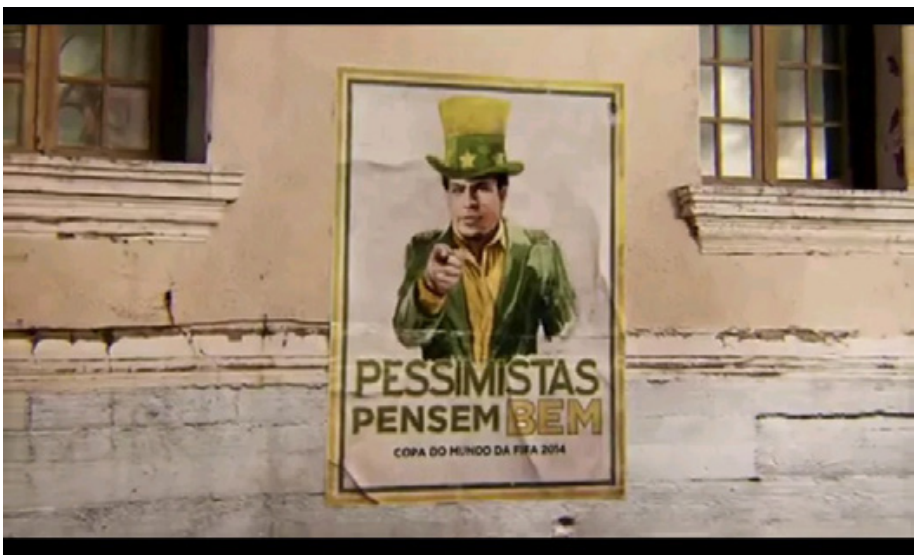

A propaganda retrata os principais problemas que podem levar o Brasil a não fazer "a melhor copa do mundo", segundo a visão considerada pessimista, como é dito no próprio anúncio (Figura 4). Dessa maneira, começa-se a mostrar que a visão otimista é muito mais recomendada nesse caso, já que o Brasil é o país do futebol e faz os melhores clássicos e também é o país do carnaval e faz as melhores festas. De forma muito otimista, artística e idealista, o comercial divulga, por exemplo, que os aeroportos estarão lotados, mas de torcedores fanáticos; os estádios estarão cheios de torcedores empolgados e atletas incríveis, como se a violência nunca estivesse presente nos estádios; e o trânsito um caos, mas o caos será causado por engarrafamentos de trios elétricos que agitarão as festas, ou seja, naquele momento todos estarão anestesiados e sem tempo para o pessimismo, já que, se trata da maior festa que poderia acontecer no Brasil. Faz-se possível o país parar por um mês para viver somente a copa do mundo e esquecer-se dos problemas que acontecem nas cidades brasileiras todos os dias (Figuras 5 e 6 ).

figura 5

Trios Elétricos.

Fonte: Comercial

da Brahma,

2014.

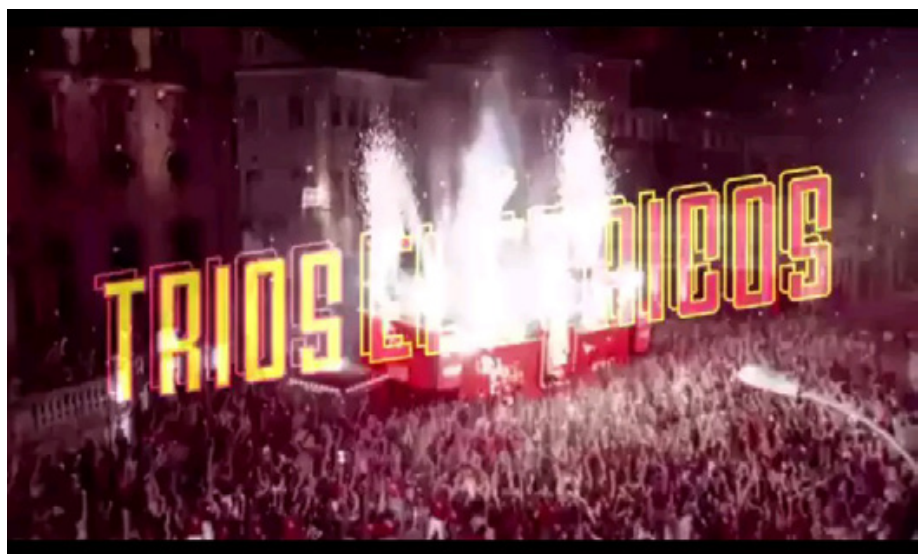


figura 7

Praias. Fonte:

Comercial da

Brahma, 2014

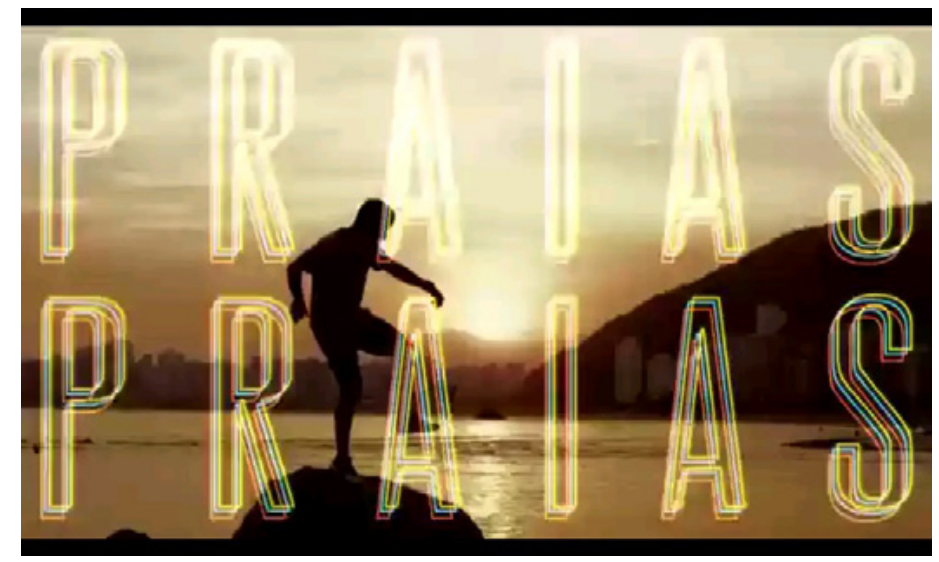

figura 8

Cidades. Fonte:

Comercial da

Brahma, 2014.

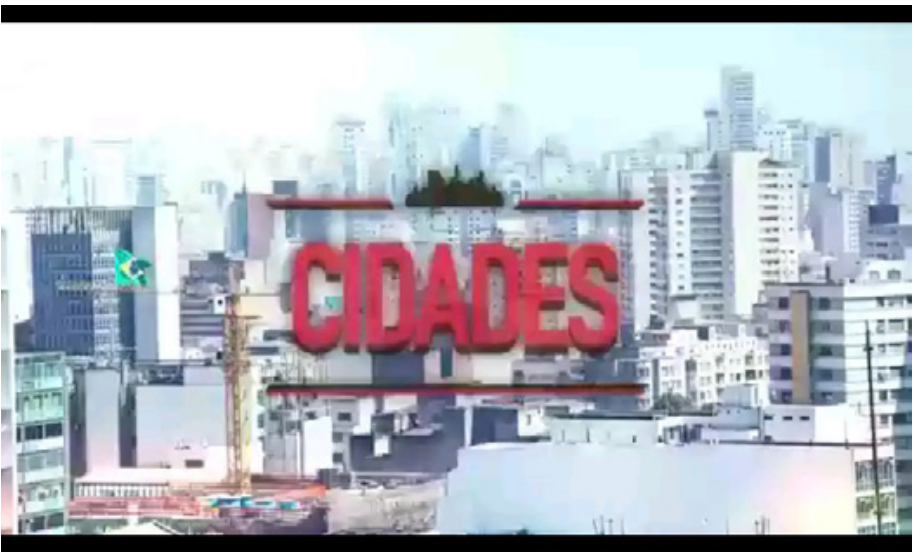

figura 9

Torcedores.

Fonte: Comercial

da Brahma,

2014.

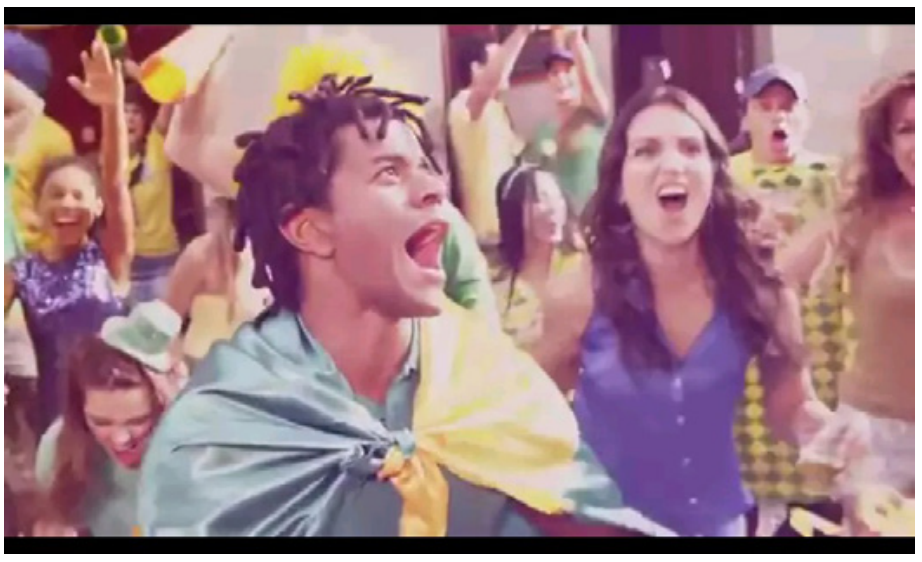

Percebe-se também uma forte preocupação em atribuir certo sentimento de orgulho nacional a quem utiliza o produto ligado a um valor de felicidade, animação, alegria, conquista e ao mesmo tempo caminha em direção à atribuição de valores que se encontram na dimensão do sensível, do impalpável.

Assim, as mensagens publicitárias desse comercial são veiculadas intensamente ao público que, consumidor ou não, submete-se ao excesso de representações e ideologias por elas manipuladas. 
Isso significa que houve a intensificação do que Baudrillard (1997) sugere. O caráter lúdico, de espetáculo e de encenação ganha lugar, em associação com imagens carregadas de representações em que a própria encenação de atores faz com que o espetáculo publicitário se intensifique. Essa encenação é alargada, pois a forma de comunicação sugerida pela agência de propaganda apresenta uma tentativa de simular certa realidade criada por eles, na qual atores aparecem em situações descontraídas e com muita felicidade.

Com as transformações econômicas do final do século XIX, a ideia de uma publicidade informativa cedeu lugar à concepção de anúncios caracterizados por apelos às emoções dos consumidores, conforme fala Ortiz (1991, 175) "A publicidade moderna já não mais se funda na utilidade dos bens apresentados, mas se dirige diretamente à imaginação, aos desejos".

As palavras e as imagens têm papel fundamental na formação dos sentidos de uma mensagem. É muito comum a utilização das imagens para expor um pensamento ou uma ideia em vez de verbalizá-lo. Sendo assim, a publicidade utiliza muito esse recurso. Por meio de imagens, consegue-se criar anúncios publicitários inteligentes, criativos e persuasivos, com base no consumo, que é o objetivo final de todo anunciante.

Usar imagens para fazer publicidade é um recurso muito vantajoso, uma vez que a percepção visual é rápida, fácil e marcante, a leitura é natural e o visual, por vezes, tem caráter universal. No entanto, o conteúdo verbal e a disposição do texto nas cenas também colaboram para a significação das mensagens veiculadas pelos anúncios. Dessa forma, a publicidade se utiliza muito dessa união bem-sucedida entre palavras e imagens.

Tanto a publicidade quanto a mídia utilizam sofisticada tecnologia visual, sonora e um arsenal de representações sociais. Isso faz com que alcancem a eficácia mercadológica de ambas e também que a produção publicitária tenha característica do processo cultural que se desenvolve no capitalismo. Assim, a publicidade é um espelho da cultura em que se insere, ao mesmo tempo em que retrata os valores sociais e ideais do momento histórico em que foi produzida.

\section{PARÓDIA}

De acordo com Linda Hutcheon, a raiz etimológica do termo vem do substantivo grego parodia, que não quer dizer apenas "contracanto", como se afirma entre a maioria dos teóricos. 0 elemento odos da palavra significa canto, no entanto, o prefixo para tem dois sentidos em grego: um, mais comum, que é o de "contra" ou "oposição" e o outro, que é o sentido menos citado, de "ao longo de". Essa segunda significação sugere 
um acordo ou intimidade ao invés de um contraste. Logo, no entender de Linda Hutcheon $(1989,48)$ :

Mesmo em relação à estrutura formal, o caráter duplo da raiz sugere a necessidade de termos mais neutros para a discussão. Nada existe em parodia que necessite da inclusão de um conceito de ridículo, como existe, por exemplo, na piada, ou burla, do burlesco. A paródia é, pois, na sua irônica "transcontextualização" e inversão, repetição com diferença. Está implícita uma distanciação crítica entre o texto em fundo a ser parodiado e a nova obra que incorpora, distância geralmente assinalada pela ironia.

É a teoria de Bakhtin, se não sempre a sua prática, que permite que se olhe para a paródia como uma forma de discurso "de direção dupla" (Hutcheon 1989, 93). A paródia tem a função de problematizar, inverter e questionar o modelo sobre o qual se estabelece. No discurso, ela tem a capacidade de inverter a estrutura ideológica, rompendo assim, modelos socialmente impostos, provocando o questionamento. Ainda segundo Hutcheon $(1989,48)$ :

Está implícita uma distanciação crítica entre o texto em fundo a ser parodiado e a nova obra que incorpora, distância geralmente assinalada pela ironia. Mas esta ironia tanto pode ser apenas bem humorada, como pode ser depreciativa; tanto pode ser criticamente construtiva, como pode ser destrutiva.

Constituindo-se a paródia, na visão bakhtiniana, como uma das formas de carnavalização, torna-se evidente a relação entre essas categorias: ambas desafiam e subvertem os dogmas e os discursos oficiais, propondo "vozes culturais" diferentes, polifônicas. Para Fiorin (2006, 97):

A paródia é ambivalente. Nela, há uma bivocalidade: a voz do parodiador e a do parodiante. Zomba-se da voz séria e, ao mesmo tempo, afirma-se uma alegria com outra voz. Com isso, nega-se o discurso de autoridade e afirma-se a relatividade das coisas.

O momento da paródia é justamente quando a percepção da carência de algo novo atinge seu limite de saturação. 0 parodiador é aquele que percebe e compreende que as ideologias precisam ser questionadas e reformuladas.

É importante notar que a paródia não se trata de um discurso caracterizado por uma crítica vazia e desconstrucionista. 0 parodiador consegue 
enxergar as lacunas e faz sugerir novas ideias e convicções que confrontam a ideologia existente. Para Hutcheon $(1989,50)$ :

Em certo sentido, pode dizer-se que a paródia se assemelha à metáfora. Ambas exigem que o descodificador construa um segundo sentido através de interferências acerca de afirmações superficiais e complemente o primeiro plano com o conhecimento e reconhecimento de um contexto em fundo.

Tendo em vista que a paródia apenas tem sentido se o leitor conhecer o texto parodiado, ela colabora para a revalorização dos textos que parodia. Desse modo, a paródia permite a análise crítica de discursos anteriores e estabelece a continuidade. Hutcheon $(1989,96)$ argumenta que:

Este paradoxo da subversão legalizada, embora não oficial, é característica de todo discurso paródico na medida em que a paródia postula, como pré-requisito para a sua própria existência, uma certa institucionalização estética que acarreta a aceitação de formas e convenções estáveis e reconhecíveis. Estas funcionam como normas ou regras que podem ser - e logo, evidentemente, serão - quebradas. Ao texto paródico é concedida uma licença especial para transgredir os limites da convenção, mas, tal como no carnaval, só pode fazê-lo temporariamente e apenas dentro dos limites autorizados pelo texto parodiado - quer isto dizer, muito simplesmente, dentro dos limites ditados pela reconhecibilidade.

0 aspecto mais interessante da paródia é que, apesar de questionadora, não entrega respostas prontas. Na verdade, convoca o leitor a realizar uma reflexão, na medida em que torna aberto o modelo.

\section{SURGIMENTO DA PARÓDIA DO COMERCIAL DA BRAHMA}

No início de fevereiro de 2014, o anúncio ganhou uma paródia produzida pelo cineasta baiano Livio Maynard. o vídeo original do comercial constrói um discurso otimista sobre a Copa do Mundo de 2014. Já a versão que tanto repercutiu nas redes sociais traz imagens reais expondo os problemas no Brasil, em contraponto ao texto dito pela campanha. A narração e alguns trechos do anúncio original são mantidos na paródia para deixar a comparação ainda mais evidente. 0 vídeo já teve mais de 40 mil 
visualizações ${ }^{13}$ desde que foi postado no Vimeo ${ }^{14}$, no início de fevereiro de 2014. Após a repercussão da produção, o vídeo acabou sendo removido do Vimeo, plataforma na qual foi postado originalmente, mas continua disponível para visualização no Youtube ${ }^{15}$ e repercutindo na maioria das redes sociais.

Não é a primeira vez que o público se apodera de uma propaganda para tratar dos problemas do Brasil. Em 2013, por exemplo, a campanha "Vem Pra Rua" da Fiat ${ }^{16}$ também ganhou uma releitura dos manifestantes. A campanha da Fiat, que convoca uma mobilização do público para torcer pela Seleção Brasileira de futebol, acabou ganhando um tom militante e virou o hino das manifestações, principalmente em São Paulo, contra o aumento da tarifa do transporte público.

Todo enunciado é social e estabelece uma réplica. De acordo com o conceito bakhtiniano, trata-se da união de sujeito, tempo e espaço.

Conforme Fiorin $(2006,32)$ :

[...] um enunciado se constitui em relação aos enunciados que o precedem e que o sucedem na cadeia de comunicação, um enunciado solicita uma resposta, resposta que ainda não existe. Ele espera sempre uma compreensão responsiva ativa, constrói-se para uma resposta, seja ela uma concordância ou uma refutação.

Quando surge uma paródia, principalmente referente às peças publicitárias, ela só tem a contribuir, uma vez que é um gênero facilmente memorizável, pois muito do que está contido nela já é conhecido e, na maioria das vezes, é de domínio público. Dessa forma, ela ajuda a fixar o nome do produto, sua ideologia e o conteúdo sócio-histórico.

\footnotetext{
13 Visualização: Ato ou efeito de visualizar ou assistir. Termo muito utilizado atualmente por usuários interativos da rede internacional Internet. Dicionário Brasileiro da Língua Portuguesa - Michaelis / online UOL. Disponível em: <http://michaelis.uol.com.br/busca?id=EZlGj>. Acesso em: 19 out. 2016.

14 Vimeo é um site de compartilhamento de vídeos em formato digital na internet. Vimeo - Sobre o Vimeo. Disponível em: <https://vimeo.com/about>. Acesso em: 19 out. 2016. 15 Youtube é um site que permite que os usuários da internet assistam e compartilhem vídeos em formato digital. Youtube - Sobre o Yuotube. Disponível em: <https://www.youtube.com/yt/about/pt-BR/>. Acesso em: 19 out. 2016.

16 Fiat é uma das marcas da Fiat Chrysler Automobiles, um dos maiores fabricantes de automóveis do mundo, com sede mundial na cidade de Turim, norte da Itália. Fiat - Institucional. Disponível em: http://www.fiat.com.br/institucional.html. Acesso em: 19 out. 2016.
} 


\subsection{A PARÓDIA CRIADORA DE NOVO DISCURSO}

A paródia que conquistou o público é argumentativa e busca, por meio da ressignificação daquilo que é do senso comum e domínio popular, transmitir um saber a partir de outro. Na paródia em análise, apesar de a fala do narrador continuar a mesma do comercial oficial da Brahma, joga-se a todo o momento com diferentes imagens que se parodiam umas às outras de diversas maneiras, apresentando um diferente ponto de vista. A paródia do comercial "Imagina a Festa" se apresenta ambivalente. Nela, o senso comum e crítico afloram e se deixam expor por imagens reais, retiradas dos mais populares noticiários do país. Dessa maneira, torna-se fácil o reconhecimento pelo público, por se tratarem de acontecimentos trágicos, diários e atuais no país.

A princípio, a paródia começa com a mesma imagem contida no comercial, a imagem do corredor cheio de troféus de campeonatos de futebol ganhos pelo Brasil, com o teto de iluminação em forma de um campo de futebol e ao centro a sambista vestida para o carnaval, sambando e transmitindo alegria como se estivesse em um desfile na avenida. Dessa maneira, a paródia reafirma o que o anúncio destaca: que o Brasil é conhecido pela paixão pelo futebol e pelo carnaval. "A paródia é uma forma de auto-referencialidade, (sic) mas isso não quer dizer que não possua implicações ideológicas" (Hutcheon 1989, 41).

Na próxima imagem do vídeo da paródia, as festas são retratadas como elas realmente são mostradas diariamente nos telejornais do país, ou seja, com violência e insegurança. Na paródia, são apresentadas as filmagens de festas que acabaram em tragédias, são imagens fortes, chocantes por serem reais. Nesse momento, a paródia instiga o público a pensar nos motivos reais que realmente poderiam prejudicar a realização do evento no país naquele momento, já que, comumente, no Brasil, não se tem segurança nem quando se está se divertindo em uma festa, seja no carnaval, reveillon ${ }^{17}$ ou em um estádio de futebol, assistindo a uma partida de seu time. Muitas tragédias como: brigas, violência sexual, furtos, roubos e mortes acontecem no país nesses eventos (Figuras 10, 11 e 12). A segurança pública para a população do país não funciona em épocas normais, então "imagina na copa”. Essa visão é criada e transmitida ao público, em forma de crítica social, não especificamente ao evento, mas ao estado em que se encontra o país, com muito a ser alcançado, resolvido, mudado e organizado. o questionamento é levantado: será que o momento não seria de planejar e organizar a casa para depois receber a visita?.

17 Réveillon: Festa, geralmente com ceia para comemorar a chegada do Ano-Novo. Dicionário Brasileiro da Língua Portuguesa - Michaelis / online UOL. Disponível em: <http:// michaelis.uol.com.br/busca?r=0\&f=0\&t=0\&palavra=reveillon>. Acesso em: 19 out. 2016. 
figura 10

Violência nos

estádios.

Fonte: Paródia

do comercial da

Brahma, 2014.
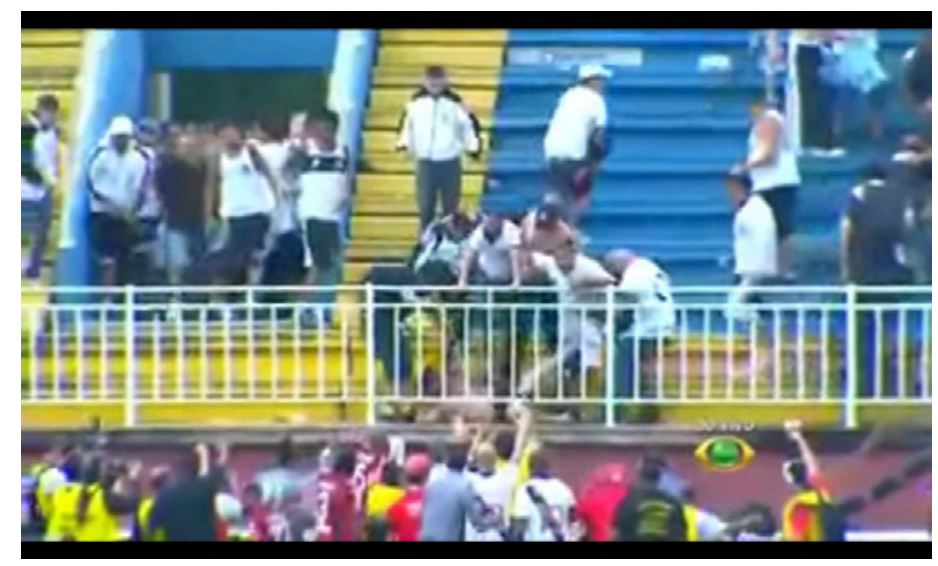

figura 11

Violência.

Fonte: Paródia

do comercial da

Brahma, 2014.

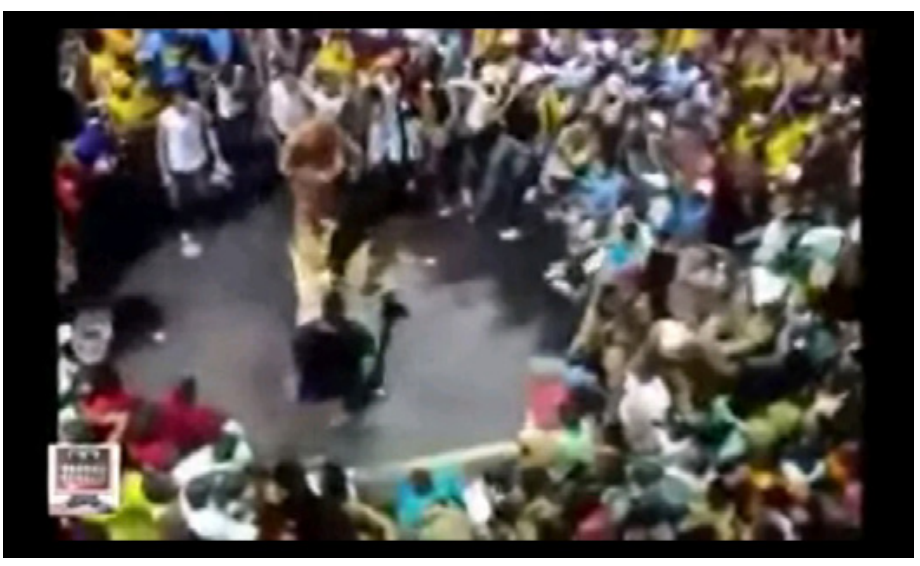

figura 12

Brigas.

Fonte: Paródia

do comercial da

Brahma, 2014.

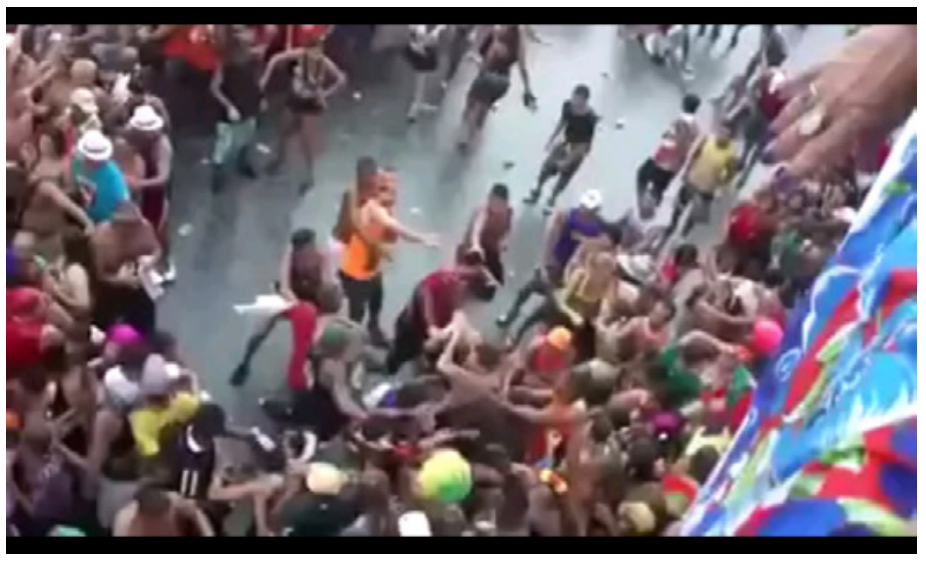

Na próxima parte da paródia, são mostradas imagens de muitos congestionamentos enfrentados todos os dias pelos brasileiros, sejam nos metrôs lotados, nas ruas com o trânsito caótico das grandes cidades ou ainda nos aeroportos com os passageiros sem informações (Figuras 13, 14,15 e 16). 
figura 13

Congestionamento.

Fonte: Paródia

do comercial da

Brahma, 2014

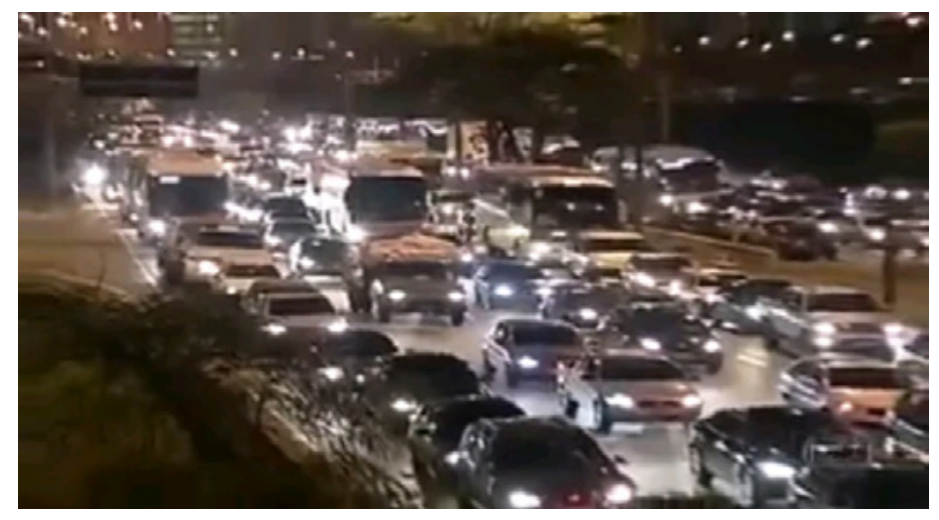

figura 14

Trânsito caótico.

Fonte: Paródia

do comercial da

Brahma, 2014.

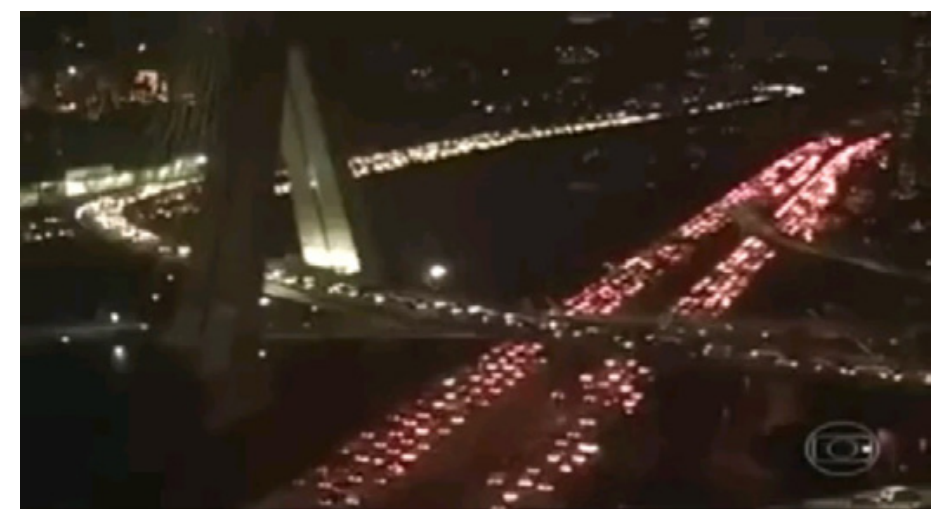

figura 15 Aeroportos.

Fonte: Paródia

do comercial da

Brahma, 2014.

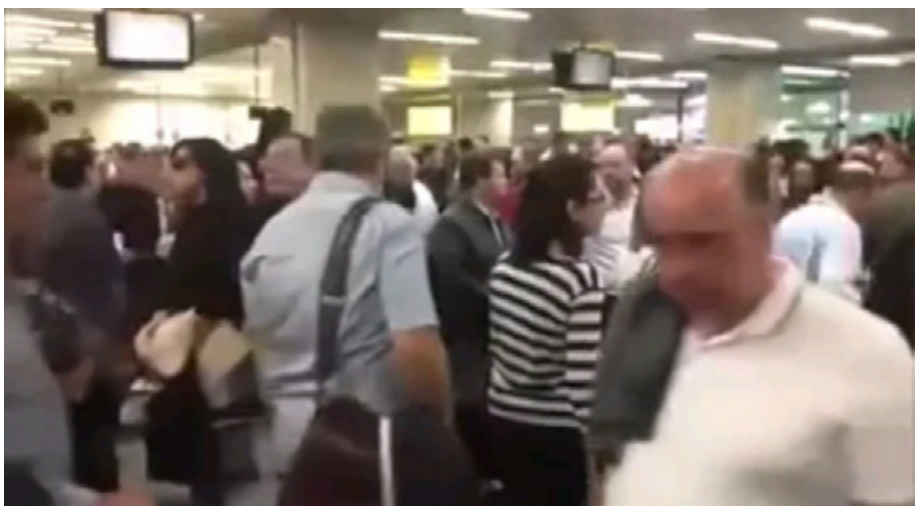

figura 16 Passageiros.

Fonte: Paródia

do comercial da

Brahma, 2014

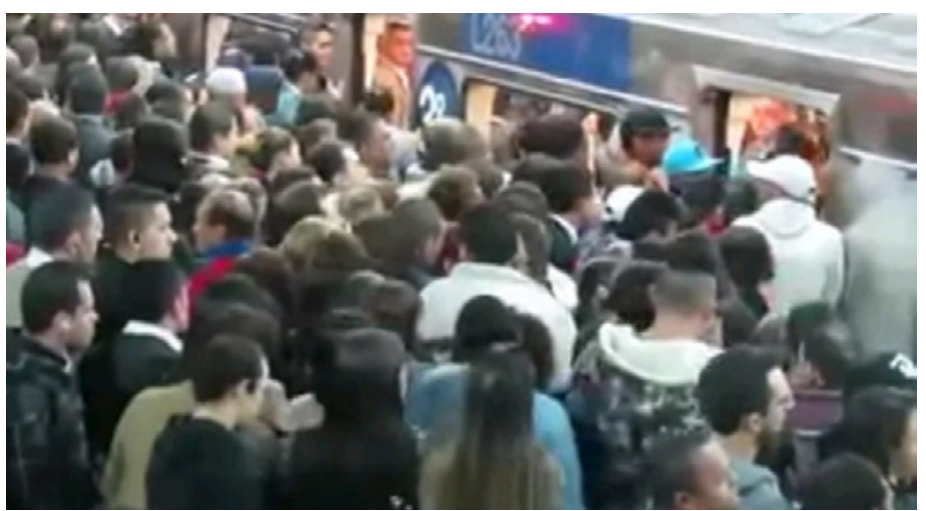


Nesse momento, apresentam-se também as imagens das praias do país, como elas são usadas e deixadas pela população, com bastante lixo, sujeiras e impurezas abandonadas nas areias e bordas das praias (Figuras 17, 18 e 19). Logo depois, são mostrados, até o final do vídeo, momentos de conflitos vividos com a polícia nas ruas, que parecem mais guerras urbanas (Figura 20).

figura 17

Praias.

Fonte: Paródia do comercial da Brahma, 2014.

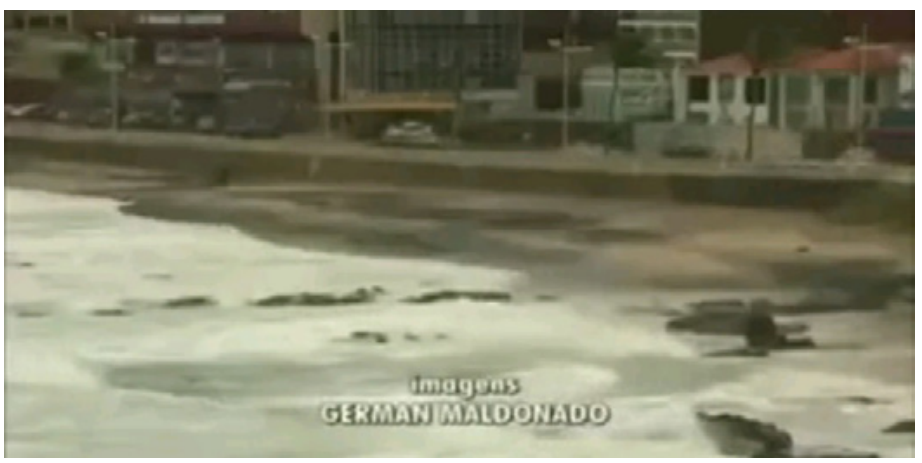

figura 18

Sujeira nas praias.

Fonte: Paródia do comercial da Brahma, 2014.

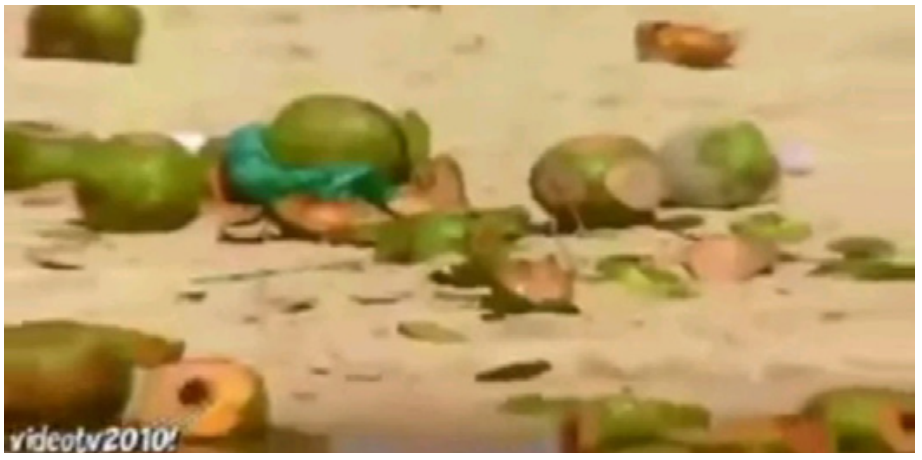

figura 19 Lixo nas cidades. Fonte: Paródia do comercial da Brahma, 2014.

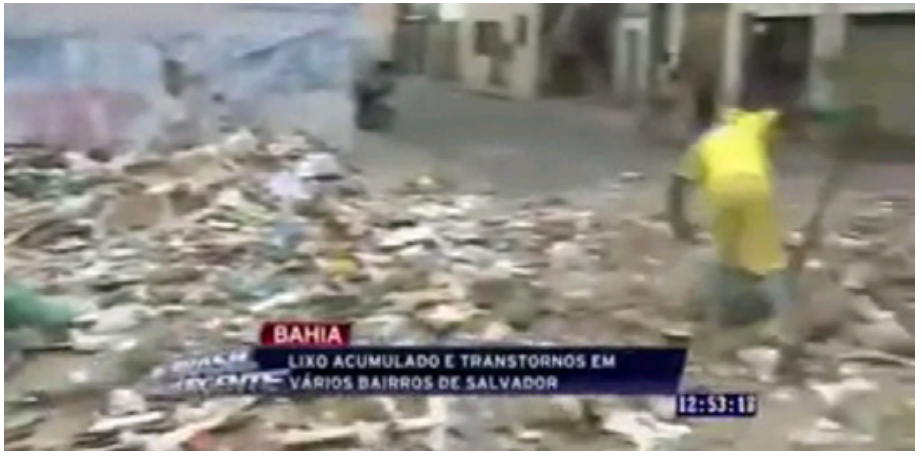

figura 20

Conflitos com a polícia.

Fonte: Paródia do comercial da Brahma, 2014.

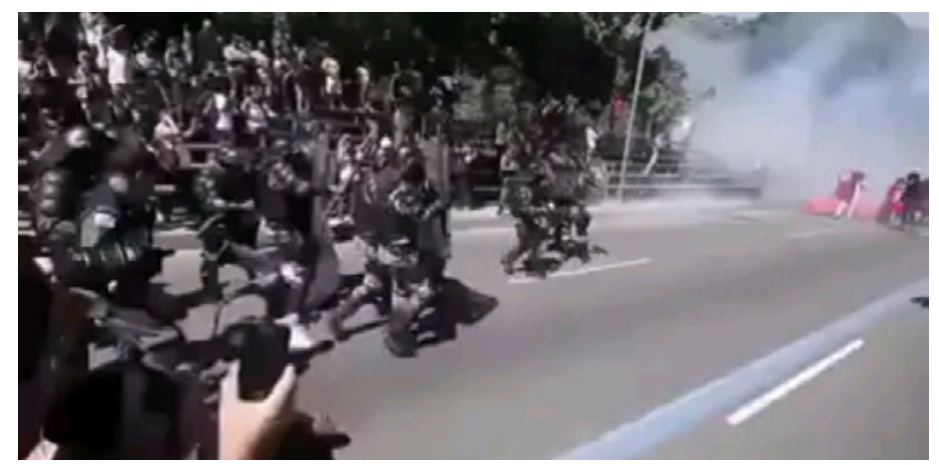


Durante a exposição das imagens lançadas no vídeo da paródia, a reprodução da narração do comercial da Brahma continua a mesma e, dessa maneira, gera-se um discurso irônico, pois, enquanto a narração do vídeo faz o apelo ao espectador: "imagina as praias; imagina as cidades; imagina o Brasil; imagina a festa", as imagens vistas pelos espectadores são assustadoramente reais e levam imediatamente ao questionamento, isto é, se seria mesmo a melhor festa já vista e se o Brasil estaria realmente pronto para receber e realizar esse evento naquele momento. "A ironia participa no discurso paródico como uma estratégia, que permite ao decodificador interpretar e avaliar" (Hutcheon 1989, 47). Dessa maneira, a paródia cria novo discurso - com teor crítico - e apresenta um novo ponto de vista ao público.

A paródia não deve ser vista sempre como uma categoria que visa à desconstrução e ridicularização de discursos anteriores. Na verdade, segundo a estudiosa Linda Hutcheon (1989), a paródia se caracteriza por uma voz que se propõe repetir de forma crítica, assinalando, desse modo, um discurso que marca a diferença em vez da semelhança. Assim, a crítica não tem de estar necessariamente presente na forma de riso ridicularizador para que um texto seja considerado paródia.

Na paródia em análise, as imagens originais e reais podem ser encontradas invertidas, ampliadas ou reduzidas, conforme as intenções do criador. Graças a esse jogo de imagens, o sentido é alterado, uma vez que apresenta nova possibilidade de leitura. Desse modo, a paródia cria novo discurso e põe em confronto uma nova visão sobre o país e sobre o evento, visto que retoma o vídeo do anúncio publicitário da Brahma de maneira invertida, destruindo para construir o novo.

Ressalte-se ainda que a importância do reconhecimento do anúncio publicitário oficial é essencial para o entendimento pleno da paródia. 0 anúncio publicitário da Brahma tem uma visão muito positiva e otimista do evento no país e também é bem animador e incentivador; na verdade, denota animação e contentamento, pois a emoção de ser realizado no Brasil o maior evento futebolístico do mundo não tem como ser medida nos brasileiros, uma vez que o Brasil é considerado o país do futebol, do carnaval e das festas, como é colocado no comercial.

No que se refere à paródia criada, a renovação e transformação do discurso transmite novo sentido dentro de outra esfera, dado que leva quem assiste a pensar, analisar e refletir de forma racional e realista os problemas sociais que os brasileiros vivenciam todos os dias e até que ponto esse evento tão popular mundialmente poderia mesmo trazer algum benefício importante a ser considerado se realizado no Brasil naquele momento, de forma tão esplêndida como aparece no anúncio da Brahma. Reconhecidamente, como forma de crítica, a paródia tem a vantagem de 
ser simultaneamente uma recriação e uma criação, fazendo da crítica uma espécie de exploração ativa da forma (Hutcheon 1989, 70).

Assim, a paródia reproduz um choque por apresentar uma postura diferente sobre o tema. Tal choque é de fácil percepção do leitor, que é o elemento central desse tipo de discurso, pois é ele quem aciona sua memória e consegue estabelecer novos sentidos e expectativas com as imagens mostradas no vídeo da paródia. Outro aspecto interessante da paródia do comercial é que, contendo outro discurso em si, ela geralmente fala sobre o que esse outro discurso (o do comercial oficial da Brahma) deixou de dizer e salienta o fato de não ter sido dito. A crítica à visão muito otimista transmitida no comercial oficial está presente a todo o momento, mostrando sempre que não se pode permanecer alienado ao tema, ao contexto sócio-histórico ou simplesmente fechar os olhos para o que acontece de verdade, sem montagem ou fantasias, no Brasil. Sob esse enfoque, leva o público a refletir sobre os problemas sociais do país. Dessa forma, a paródia possibilita a revisão crítica de discursos, o que promove a manutenção e o surgimento de discursos posteriores.

\section{CONSIDERAÇÕES FINAIS}

Nesta análise, constatou-se, segundo Bakhtin, que todo discurso é dialógico porque o dialogismo é constitutivo da linguagem. Visto que o discurso de um se inscreve no discurso do outro e sabendo-se que dialogismo são relações entre enunciados, pode-se dizer que os discursos são dialógicos porque resultam do embate de visões diferentes; no entanto, apenas um ponto de vista se apresenta. Os vídeos analisados apresentam diferentes perspectivas que se defrontam e entram em choque, manifestando diferentes posicionamentos sobre o mesmo assunto, já que cada um dos vídeos analisados possui um conceito dominante presente em seus discursos.

Sendo a paródia um discurso que emite um posicionamento, uma opinião, o que se diz tem que remeter sempre para o já dito, uma vez que o discurso parodístico jamais se desvia da influência que o outro parodiado exerce sobre si. Na paródia em análise, verificou-se a presença de um ponto de vista dominante no discurso, portanto, confirma-se a afirmação de que a paródia dialoga e emite opinião. Assim, constata-se a presença do dialogismo no gênero paródia.

Ambos os processos artísticos - propaganda e paródia - visam à busca de novas leituras; novos sentidos; novas formas de conhecer e de ser conhecido. Ao deparar com a paródia do comercial da Brahma "Imagina a Festa", não só o produto passa a ser conhecido, mas também a própria ideologia, tanto do público como da sociedade, do veículo de divulgação, enfim, dos sujeitos envolvidos na comunicação, bem como todo o conteúdo sócio-histórico. 
Conclui-se, então, que a paródia possibilita a revisão crítica de discursos, promovendo, consequentemente, a manutenção deles. 0 público, ao compreender o significado do que é dito ou do que é desejado dizer, é o responsável por completá-lo e aplicá-lo, ou seja, tem a autonomia de concordar ou discordar do discurso proposto. Assim, o que foi visto ou ouvido sempre irá refletir e responder aos discursos posteriores. Dessa maneira, o texto parodiado sempre é valorizado e perpetuado, mesmo quando o parodiador critica, debocha ou ridiculariza. A paródia caminha da crítica cruciante à valorização implícita dos conteúdos parodiados.

\section{REFERÊNCIAS BIBLIOGRÁFICAS}

Bakhtin, Mikhail. 2000. Estética da criação verbal. Tradução de Maria Ermantina Galvão; revisão de tradução de Mariana Appenzeller. $3^{a}$ ed. São Paulo: Martins Fontes.

Bakhtin, M. (Volochinov, V.N.). 1988. Marxismo e filosofia da linguagem: problemas fundamentais do método sociológico na ciência da linguagem. Trad. Michel Lahud e Yara F. Vieira. São Paulo: HUCITEC.

Barthes, Roland. 1987. Mitologias. Rio de Janeiro: Bertrand Brasil.

Baudrillard, Jean. 1995. A sociedade de consumo Rio de Janeiro: Elfos, 1995: Ed. 70.

1997. O sistema dos objetos. Trad. Zulmira Ribeiro Tavares. $3^{a}$ ed. São Paulo, Perspectiva.

Bigal, Solange. 1999. O que é criação publicitária ou (O estético na publicidade). $2^{\text {a }}$ ed. São Paulo: Nobel.

Bouer, J. 2006. Tudo sobre álcool, cigarro e drogas. São Paulo: Editora Melhoramentos.

Brait, Beth. 1997. Bakhtin e a natureza constitutivamente dialógica da linguagem. In: Brait, Beth. (Org.). Bakhtin, dialogismo e construção de sentido. Campinas: UNICAMP.

Bucci, Eugênio. 2002. A fabricação de valor na super indústria do imaginário. Communicare: revista de pesquisa. São Paulo, Cásper Líbero, 2002. v.2.

Dondis, Donis A. 2003. Sintaxe da linguagem visual. $2^{\mathrm{a}}$ ed. São Paulo: Martins Fontes.

Fiorin, José Luiz. 2006. Introdução ao pensamento de Bakhtin. São Paulo: Ática.

Hutcheon, Linda. 1989. Uma teoria da paródia: ensinamentos das formas de arte do século XX. Trad. Tereza Louro Pérez. Lisboa: Edições 70.

Marchezan, R. C. Diálogo. 2006. In: Brait, Beth (Org.). Bakhtin: outros conceitos-chave. São Paulo: Contexto. 
Martins, Jorge S. 1997. Teoria e prática: textos publicitários. 5ª ed. São Paulo: Ática.

Ortiz, Renato. 1991. Cultura e modernidade: a França no século XIX. São Paulo: Brasiliense.

Pinsky, I. 2009. Publicidade de bebidas alcoólicas e os jovens. São Paulo: FAPESP.

Tavares, Fred. 2005. Discurso publicitário e consumo: uma Análise Crítica. Rio de Janeiro: E-papers.

Velmezova, E. 2005. Mikhail Bakhtin, o mecânico e as fronteiras. In: Zandwais, Ana (Org.). Mikhail Bakhtin: contribuições para a filosofia da linguagem e estudos discursivos. Porto Alegre: Sagra Luzzato.

Verón, Eliseo. 1980. A produção de sentido. São Paulo: Cultrix.

Zavala, Íris. 2009. 0 que estava presente desde a origem. Trad. Fernando Legón e Diana Araújo Pereira. In: Brait, Beth (Org.). Bakhtin, dialogismo e polifonia. São Paulo: Contexto.

A história da Coca-Cola. Disponível em: <http://www.cocacolabrasil.com.br/sobre-a-cocacola-brasil/a-historia-da-coca-cola-brasil>. Acesso em: 19 out. 2016.

Aristóteles Biografia. Disponível em: <http://www.pucsp.br/pos/cesima/schenberg/alunos/ paulosergio/biografia.html>. Acesso em: 19 out. 2016.

Cervejas Brahma. Disponivel em: <http://www.ambev.com.br/marcas/cervejas/brahma/ brahma-chopp/>. Acesso em: 19 out. 2016.

ComercialdaBrahma. Disponivelem: <http://www.youtube.com/watch?v=Wkw7xptwBAg.> Acesso em: 28 fev. 2014.

Dicionário Brasileiro da Língua Portuguesa - Michaelis / online UOL. Disponível em: <http:// michaelis.uol.com.br/busca?id=V4wnz>. Acesso em: 19 out. 2016.

. Disponível em: <http://michaelis.uol.com.br/busca?id=EZIGj.> Acesso em: 19 out. 2016.

. Disponivel em: <http://michaelis.uol.com.

brbusca?r=0\&f=0\&t=0\&palavra=reveillon>. Acesso em: 19 out. 2016.

Fiat - Institucional. Disponivel em: <http://www.fiat.com.br/institucional.html.> Acesso em: 19 out. 2016.

McDonald's - Quem somos. Disponível em: <http://www.mcdonalds.com.br/>. Acesso em: 19 out. 2016. 
Microsoft - Institucional. Disponivel em: <https://www.microsoft.com/pt-br/about/nossacompanhia.aspx>. Acesso em: 19 out. 2016.

Nokia Company - About us. Disponivel em: <http://company.nokia.com/en/about-us/ourcompany>. Acesso em: 19 out. 2016.

Paródia da Brahma. Disponivel em: <https://www.youtube.com/watch?v=p5w7D47JP6c.> Acesso em: 28 fev. 2014.

Ronaldo Fenômeno - História de vida. Disponivel em: <http://esporte.ig.com.br/futebol/ ronaldo//1237863664000.html>. Acesso em: 19 out. 2016.

Sobre a GE. Disponível em: <https://www.ge.com/br/sobre>. Acesso em: 19 out. 2016.

Sobre a IBM. Disponível em: <https://www.ibm.com/ibm/br/pt/?lnk=fsi-saib-brpt.> Acesso em: 19 out. 2016.

Vimeo - Sobre o Vimeo. Disponível em: <https://vimeo.com/about>. Acesso em: 19 out. 2016.

Visão geral sobre a empresa Intel Inside. Disponível em: <www.intel.com.br/content/www/ br/pt/company-overview/company-overview.html>. Acesso em: 19 out. 2016.

Walt Disney Company - About. Disponivel em: <https://thewaltdisneycompany.com/ about/>. Acesso em: 19 out. 2016.

Youtube - Sobre o Youtube. Disponível em: <https://www.youtube.com/yt/about/pt-BR/>. Acesso em: 19 out. 2016.

\section{CAMILA DE ARAÚJO BERALDO LUDOVICE}

Possui graduação em Letras-Habilitação em Português e Inglês pela Universidade de Franca, é Mestre em Linguística e Doutora em Linguística e Língua Portuguesa pela FCLAR - Unesp (Araraquara). Atualmente é professora permanente do Programa de Pós Graduação em Linguística (Mestrado) da Universidade de Franca e professora do curso de Letras. Áreas de atuação e conhecimento: Linguística, Estudos Bakhtinianos, Análise do Discurso, Semiótica, Língua e Literatura Latina.

\section{LAYD GLAUCE FONTANEZI NOGUEIRA}

Possui graduação em Letras - Habilitação em Português e Inglês; Bacharerecebido lado em Administração de Empresas e Especialização em Estudos Linguísticos e Literários pela Universidade de Franca. Atualmente é professora em escola estadual; de idiomas e dos cursos técnicos - CTEC da Universidade de Franca. Tem experiência na área de Letras, Linguística e Comunicação. 